This is a pre-copyedited, author-produced version of an article accepted for publication in Notes \& Queries following peer review. The version of record Rudolf, Winfried. "The Earliest Surviving Homily in English." Notes \& Queries 66:1 (2019), 24-26.

is available online at: https://doi.org/10.1093/notesj/giy185

The publication was produced in the context of ECHOE - Electronic Corpus of Anonymous Homilies in Old English. This project has received funding from the European Research Council (ERC) under the European Union's Horizon 2020 research and innovation programme (Grant No. 772744).

\title{
THE EARLIEST SURVIVING HOMILY IN ENGLISH
}

In an important contribution to Anglo-Saxon England Donald G. Scragg recently identified the palimpsest in Oxford, Bodleian Library, MS Digby 63(=Arch. F. e. 6), fol. 9r, lines 1-2, as the earliest surviving traces of an Old English homily, which can be dated to between 844 and $867 \mathrm{AD}$ and associated with Northumbria. ${ }^{1}$ Neil R. Ker had recorded these remnants of writing as a scribble reading '[...]gað monn on ðissum bocum pæt ure [...]as', already

\footnotetext{
${ }^{1}$ D. G. Scragg, 'A Ninth-Century Old English Homily from Northumbria', ASE, 45 (2017), 39-49. For the dating see D. N. Dumville, 'Motes and Beams: Two Insular Computistical Manuscripts', Peritia 2 (1983), 24856, and more recently his 'English Script in the Second Half of the Ninth Century', in Latin Learning and English Lore: Studies in Anglo-Saxon Literature for Michael Lapidge, ed. K. O'Brien O'Keeffe and A. Orchard, 2 vols. (Toronto, 2005) I, 303-25, esp. 308-9. See also H. Gneuss and M. Lapidge, Anglo-Saxon Manuscripts: a Bibliographical Handlist of Manuscripts and Manuscript Fragments Written or Owned in England up to 1100 (Toronto, 2014), no. 611; A. G. Watson, Catalogue of Dated and Datable Manuscripts c. 435-1600 in Oxford Libraries, 2 vols. (Oxford, 1984) I, no. 419. The date 844 is suggested by W. M. Stevens, Cycles of Time and

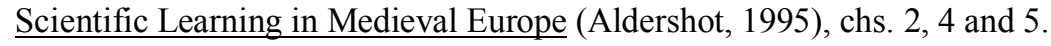


noticing the characteristic sound of a homiletic opening. ${ }^{2}$ Scragg's demonstration of how the Digby 63 palimpsest echoes the beginning of Vercelli homily XV ('Men pa leofestan sægð us on pyssum bocum hu se halga Thomas [...]') is convincing, while it confirms Ker's suggestion of a pastoral address. ${ }^{3}$ There is not only a notable similarity in the wording of these clauses, but also in the single capital $<\mathrm{M}>$ combined with a macron as abbreviation for Men pa leofestan at the beginning, which the Digby homily may have shared with the group of Vercelli homilies XV-XVIII. ${ }^{4}$ Using a set of multispectral images of Digby 63, fol. 9r Scragg expands Ker's reading of this fragmentary homily's beginning to:

1 [Men pa leofestan] sagað monn on ðissum bocum pæut ure

$2 \quad[\ldots] \mathrm{f}[\ldots]$ wias. $[\ldots] .^{5}$

Scragg's conjecture on line 2 showing the third person present indicative form frætewias of the OE verb (ge)fræt(e)wian ('to adorn, to ornament'), which he corrects to frætwias in the final footnote of his article, takes the -as ending as a marker of the Northumbrian dialect. ${ }^{6}$

${ }^{2}$ N. R. Ker, A Catalogue of Manuscripts Containing Anglo-Saxon (Oxford, 1957), no. 319. As a matter of habit, Ker does not indicate abbreviations in his incipits.

${ }^{3}$ See Vercelli, Biblioteca Capitolare, MS CXVII ('The Vercelli Book'), fol. 80v/8 and Scragg, 'A Ninth Century Homily', 42-5. For an edition see The Vercelli Homilies and Related Texts, ed. D.G. Scragg, EETS os 300 (Oxford, 1992), 253.

${ }^{4}$ See Vercelli, Biblioteca Capitolare, MS CXVII, fols. 80v, 85v, 90v, 95r and Scragg, 'A Ninth-Century Homily', 42. For a digital facsimile of the Vercelli Book see http://vbd.humnet.unipi.it/beta2/index.html (accessed 30/10/2018). Scragg has suggested a connection in both language and layout of these four Vercelli homilies in 'The Compilation of the Vercelli Book', ASE 2 (1973), 189-207, esp. 194 and 202-3.

${ }^{5}$ Scragg does not print the full opening anywhere, so this is a reconstruction of his selective readings (Scragg, 'A Ninth-Century Homily', 42, 46, 49, including his self-correction in the final footnote).

${ }^{6}$ Ibid., 47 and 49. 
However, neither form is a tenable reading. Digital image manipulation of the multispectral images reveals that the palimpsest in fact reads: ${ }^{7}$

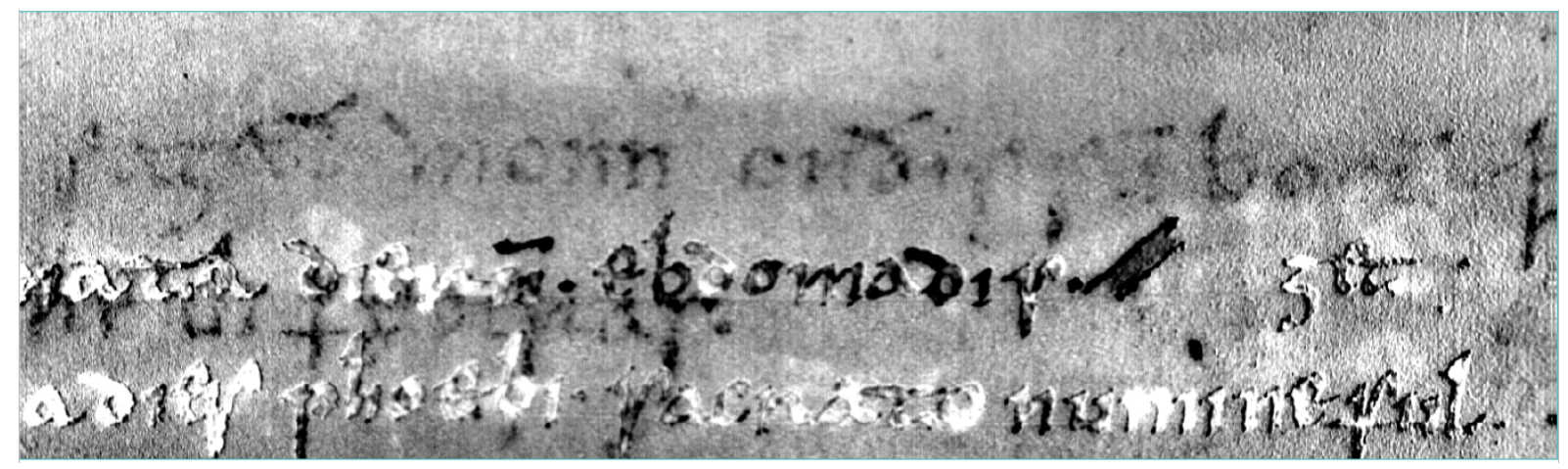

Table 1: Oxford, Bodleian Library, MS Digby 63, fol. 9r (detail, multispectral image). (C) The Bodleian Library, University of Oxford

1 [Men pa leofestan] sagað monn on ðissum bo[c]um pæat ure he[a]hfederas. [...].

Of the word heahfederas in line 2 the limbs of both $<\mathrm{h}>$ are clearly visible, the second $<\mathrm{h}>$ showing the prominent spatula leaning to the left that is typical of this hand, which is probably identical with the main hand that wrote the Canterbury Computus over the erased text. ${ }^{8}$ We may therefore assume an English origin for this scribe, regardless of where this

\footnotetext{
${ }^{7}$ I owe thanks to Dr Martin Kauffmann and David Howell at the Bodleian Library for providing me with a set of multispectral images of fol. 9r. On the techniques of digital manipulation of manuscript images to improve legibility see Peter A. Stokes, 'Recovering Anglo-Saxon Erasures: Some Questions, Tools and Techniques', in Palimpsests and the Literary Imagination of Medieval England, ed. by Leo Carruthers, Raeleen Chai-Elsholz and Tatjana Silec (New York, 2011), 35-60.

${ }^{8}$ For the development of the computus see Byrhtferth's Enchiridion, ed. P. S. Baker and M. Lapidge, EETS ss 15 (Oxford, 1995), xl-lx.
} 
person was working. ${ }^{9}$ The letter $<\mathrm{e}>$ is raised by this scribe in all three instances of heahfederas. The round shape of $<\mathrm{d}>$ can be discerned without difficulty. What Scragg misreads as the combination $<\mathrm{pi}>$ is in fact an $<\mathrm{r}>$, which shows a wide funnel throughout the entire manuscript (see for example ure in line 1) and is generally very inconsistent in the length of its descender. ${ }^{10}$ It is usually ligatured with the preceding raised $<\mathrm{e}>.{ }^{11}$

The reading heahfederas also makes sense within the context of this opening clause, in which homilies frequently refer to an authoritative source, often biblical. ${ }^{12}$ Ure heahfederas is a plausible collocation found elsewhere in homilies and it is unlikely that a word is missing between the two in Digby $63 .{ }^{13}$ Instead, we may assume that the space to the left of heahfederas was occupied by the capital $<\mathrm{M}>$ of the Men pa leofestan-abbreviation, a letter which may therefore have been at least two lines in height, on top of which the still visible macron was placed. ${ }^{14}$ This capital would have indented the beginning of line 2 accordingly.

\footnotetext{
${ }^{9}$ On the potential origins of the manuscript see D. N. Dumville, 'English Script in the Second Half of the Ninth Century', esp. 308-9 and Scragg, 'A Ninth-Century Homily', 47.

${ }^{10}$ See for example reliquas $(25 \mathrm{r} / 1)$; partem $(25 \mathrm{r} / 15)$; $\underline{\operatorname{argumentum}}(25 \mathrm{r} / 18)$; kalendarum $(25 \mathrm{r} / 19)$ in Digby 63.

${ }^{11}$ Compare with <er>-ligatures of this scribe in mercurius $(9 r / 6)$; evenerit $(9 r / 18)$; erant $(25 r / 3)$ with varying length of the descender of the $<\mathrm{r}>$.

${ }^{12}$ See for example the beginnings of Vercelli homilies V, VIII, and XXII: The Vercelli Homilies and Related $\underline{\text { Texts, }}$ ed. Scragg, 111, 143, 368.
}

${ }^{13}$ A reference to ure heahfæderas occurs, for example, in Assmann homily IX (Angelsächsische Homilien und

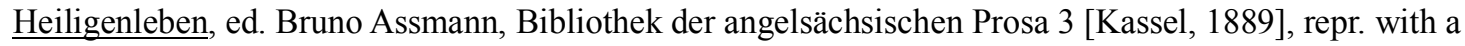
supplementary introduction by Peter Clemoes [Darmstadt,1964], 102-16, line 221) and Tristram homily IV (Hildegard L. C. Tristram, 'Vier altenglische Predigten aus der heterodoxen Tradition, mit Kommentar, Übersetzung und Glossar sowie drei weiteren Texten im Anhang.' [Diss. U Freiburg im Breisgau, 1970], 17385 , line 53).

${ }^{14}$ For its potential size compare the initials mentioned in footnote 4 and see Scragg, 'A Ninth-Century Homily', 45. 
The use of this capital $<\mathrm{M}>$ with macron is remarkable because it indicates that a routine form of abbreviation for the common homiletic address in Old English (similar to the widespread Latin fratres karissimi) was established by the mid-ninth century. This may hint at least at a few years of previous codification of Old English homilies. ${ }^{15}$

The Northumbrian association of Digby 63 has been pointed out on account of the inclusion of the northern saints Cuthbert, Wilfrid, John of Beverley, and Oswald in the calendar, who are specially marked with a cross. ${ }^{16}$ While, as seen above, Scragg's reconstruction of a Northumbrian -as verb-inflection cannot be retained, the spelling heahfederas nevertheless supports an Anglian origin, with the form feder frequently occurring in the contemporary Vespasian Psalter gloss. ${ }^{17}$ I therefore agree with Scragg to the extent that we can almost certainly 'exclude the possibility that this sheet [fol. 9r] at least - and presumably the whole of the book - was written on the Continent.'

It is difficult to speculate about the contents of this lost homily, but the reference to the patriarchs (e.g. Adam, Enoch, Noah, Abraham, or Moses) at least implies that this early pastoral address in the English language did not expound a pericope, but treated one or more

\footnotetext{
${ }^{15}$ The single-letter abbreviation is not, as Scragg (2017: 43) suggests, exclusive to the Vercelli Book. See, as one of various examples, Oxford, Bodleian Library, MS Junius 85/86, fol. 3r. Regular preaching in England was prescribed by the Council of Clofesho in 747 AD; see A. W. Haddan and W. Stubbs, eds., Councils and
} Ecclesiastical Documents Relating to Great Britain and Ireland, 3 vols. (Oxford, 1869-1878), III, 367. When the codification of vernacular homilies began is uncertain. The Admonitio generalis of 789 encouraged vernacular preaching throughout the Carolingian empire. For the influence of the $\underline{\text { Admonitio generalis }}$ and related legislation on the development of the Carolingian sermon, see Thomas L. Amos, "Preaching and the Sermon in the Carolingian World," in De ore Domini: Preacher and Word in the Middle Ages, ed. Thomas L. Amos, Eugene A. Green, and Beverly M. Kienzle (Kalamazoo, 1989), 41-60, at 43-44.

${ }^{16}$ Richard W. Pfaff, The Liturgy in Medieval England: A History (Cambridge, 2009), 71-2.

${ }^{17}$ K. Brunner, Altenglische Grammatik, 3rd ed. (Tübingen, 1965), §285, 3a; A. Campbell, Old English Grammar (Oxford, 1959), §164; The Oldest English Texts, ed. H. Sweet, EETS os 83 (London, 1885), 220, 315,333 et al. 
catechetical topics, the first of which referred in some way to the Old Testament or its apocrypha. ${ }^{18}$ Its scribe began this vernacular piece on a fresh quire and was then perhaps ordered to abandon the task to reuse the gathering for the more prestigious Latin computus.

University of Göttingen

WINFRIED P. RUDOLF

\footnotetext{
${ }^{18}$ An Old English homily that opens with a direct reference to the patriarchs is Blickling homily IX, a short piece on the meaning of Christ's coming into this world, sometimes associated with Tuesday in Rogationtide (the rubric in the manuscript has been erased); see The Blickling Homilies of the Tenth Century, ed. R. Morris, EETS os 73 (London, 1880), p. 105: 'Men pa leofestan, we gehyrdon oft secggan be pam æpelan tocyme ures Drihtnes hu he him on pas world pingian ongan, pæt heahfæderas sægdon \& cypdon, pæt witigan witigodan \& heredon, pæt sealmsceopas sungon \& sægdon, pæt se wolde cuman of pam cynestole \& of pæm prymrice hider on pas world [...].'
} 